\title{
Outros olhares sobre a fotografia
}

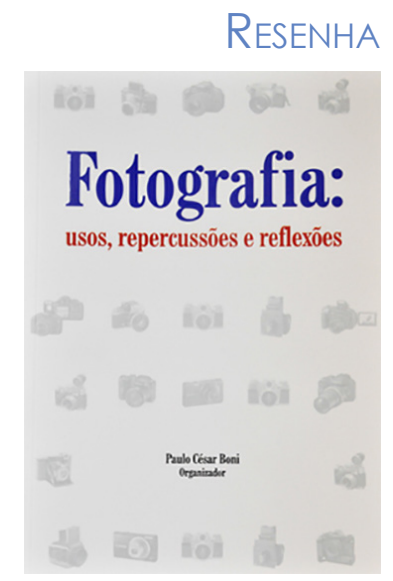

L Carlos do Amaral

Mestrando em Comunicação pela Universidade Municipal de São Caetano do Sul.

E-mail: carlaomestre@hotmail.com

A maioria das pessoas gosta de tirar fotos e essa atividade vem ganhando espaço cada dia maior nos trabalhos acadêmicos. Um deles é o livro que tem como organizador Paulo César Boni: Fotografia: usos, repercussões e reflexões. O autor tem em seu histórico um doutorado e está fazendo pós-doutorado em Ciências da Comunicação pela Universidade de São Paulo.

Ana Taís Martins Portanova Barros apresenta o seu artigo Fotografia, olho do pai. Em um primeiro momento, a autora faz um levantamento para se conhecer o que existia sobre fotografia no diretório de teses e dissertações da Capes (Coordenação de Aperfeiçoamento de Pessoal de Nível Superior) e do diretório de grupos de pesquisa do CNPq (Conselho Nacional de Desenvolvimento Científico e Tecnológico). Nesse levantamento, a área de Comunicação ficou com $51,10 \%$ das publicações. Em segundo ficou História, com 15,65\%, sendo que o restante de 35,45\% estava nas áreas de Antropologia, Arquitetura e Urbanismo, Ciências da Informação, Educação e Sociologia. Descreve, ainda, quem eram os autores mais citados nos trabalhos. Por fim, aplica questionário online para conhecer a concepção popular de fotografia, ao qual 245 pessoas responderam. A conclusão da autora é que, para a ciência a fotografia é um espelho do mundo e, para os populares, ela é uma janela do mundo. "Janela ou espelho, na base das duas imagens se encontra a fé na existência de uma realidade que está lá, esperando para ser enquadrada" (p. 40).

O segundo artigo é A proposta metodológica do uso da fotografia como disparadora do gatilho da memória, dos autores Paulo César Boni e Juliana de Oliveira Teixeira. Esse estudo aconteceu após o Grupo de Pesquisa "Comunicação e História”, do CNPq,

$148 \frac{\text { Comunicação \& Inovação, PPGCOM/USCS }}{\text { v. 16, n. } 30 \text { (148-151) jan-abr } 2015}$ 
apresentar um método em que a fotografia iria, em conjuntamente à história oral, recuperar o histórico de cidades e organizações. $\mathrm{O}$ objeto descrito aconteceu na cidade de Telêmaco Borba (PR). A expressão de "disparar o gatilho da memória" tem como fundamento a apresentação de fotos aos entrevistados, o que tornaria mais fácil o acesso às lembranças. Após as entrevistas acompanhadas da exibição das fotos, os autores concluem que esse método contribui para se descobrir histórias antes não conhecidas.

Fotografia, gatilho de memórias é o título do terceiro artigo elaborado por Maria Luísa Hoffmann. O foco do trabalho é semelhante ao do segundo artigo. O local, contudo, passa a ser a cidade de Londrina (PR). A explicação do procedimento para se levantar os dados é fornecida com maior aprofundamento nesse artigo. A autora conclui que "com a análise da imagem fotográfica aliada aos microrrelatos pessoais, um novo olhar sobre a história pode ser construído e enriquecido. (...) Por meio da documentação - imagética e oral -, a memória é perpetuada, revisitada e interpretada" (p. 91-92).

Fabio Gomes Goveia e Lia Scarton Carreira são os autores de Fotografia e Big Data: implicações metodológicas. Segundo os autores, Big Data são gigantescos conjuntos de dados. O Labic - Laboratório de Estudos sobre Imagem e Cibercultura, onde os autores e sua equipe fazem seus experimentos nas redes sociais, pode receber conjuntos com um número de 100 mil imagens. $O$ estudo se deu acerca dos protestos de junho de 2013 no Estado do Espírito Santo. Mil imagens foram coletadas das redes sociais Facebook e Instagram. Todo o conteúdo foi arquivado e catalogado. Após os analisarem, os autores chegaram à conclusão de que "A utilização de novas ferramentas de visualização de grandes conjuntos de dados abre ao campo de análise de imagens imensos desafios e perspectivas promissoras" (p. 111).

Fabiane Aline Alves e Paulo César Boni são os autores do quinto texto do livro: O ensaio da fotografia como auxílio de recursos audiovisuais. O seu objetivo é entender a implantação de inovações tecnológicas, como as aulas em DVD na disciplina de fotojornalismo. Foram aplicadas três tipos de entrevistas aos alunos: uma fechada, uma semiestruturada e por fim uma semiaberta. Um total de $60 \%$ dos pesquisados acreditava que o aprendizado por meio dos DVDs é grande, mas que era importante ter os trabalhos práticos e discussão sobre o tema nas aulas. "Considera-se necessário para o ensaio de fotografia no ensino superior o diálogo entre as novas tecnologias e participação ativa do professor como mediador" (p. 132).

A segunda parte do livro tem início com artigo $O$ ato fotográfico como susticidade midiática: representação, fotojornalismo e arte, do autor Emerson dos Santos Dias. "A imagem antes de ser representação com determinada intenção ou pretensão de refletir o real, é operação de montagem que resulta de um laborioso trabalho com referências a 
outras imagens, códigos e formas de representação que condenam nossos modos de ver e mostrar as coisas (...)" (p. 148). O autor crê que algumas imagens são consideradas jornalísticas em primeiro momento e encaradas como "artísticas" em outra oportunidade. Pois, ao capturar determinado ponto, principalmente o da tristeza, o sentimento pode ser repassado ao olhar do outro.

A estética como ferramenta de análise das fotografias de James Nachtwey é o artigo de Simonetta Persichetti e Diego Luciano Pontes. O foco fica na importância da fotografia de guerra, trabalho que deve considerar o peso dos valores morais ao se registrar o sofrimento das pessoas, algo que demanda seriedade adicional do fotógrafo. Para os autores, a percepção do público pode ser diferente sobre a guerra, mostrando que além dos combatentes existem pessoas vivendo naquelas regiões, mesmo durante os embates dos exércitos. Persichetti e Pontes chegam à conclusão que "em suma, as imagens de conflitos contribuem para deixar latente em nossa consciência o horror da guerra e a crueldade que o homem é capaz de cometer. (...) Suas representações imagéticas, portanto sempre nos servirão como uma terapia de regressão, não nos deixando alheios aos problemas da humanidade" (p. 175).

Xamanismo Visual: a noção do indizível na fotografia de Claudia Andujar, tem como autores Isaac Antonio Camargo e Stela Maris Munhoz. Nesse artigo são analisados os trabalhos da fotógrafa nos rituais da tribo Yanomani onde as simbologias mais relatadas são a morte e o renascimento. "A parte da obra de Claudia Andujar dedicada ao povo Yanomani traceja por uma via menos lapidada, pouco vaidosa, quer dizer, a beleza de sua fotografia encontra-se nas entrelinhas, pois a sua pretensão não era o espetáculo, e sim gerar a conscientização" (p. 204). Os autores entendem que o que é transmitido por Andujar é uma noção do que os rituais xamânicos significam, pois esses momentos, além de únicos, podem ser considerados sagrados.

O penúltimo artigo é de Pedro Afonso Vasquez, denominado Sonhos Verdadeiros: a fotografia de Duane Michals. "A preocupação básica de Michels era a de explicar que sua fotografia não efetuava o registro de um fato concreto - uma pessoa, um local, um objetivo ou uma ação determinada - é sim uma criação pessoal independente" (p. 218). Segundo o autor, os trabalhos de Duane Michals são consagrados internacionalmente pois sua originalidade e independência são muito marcantes, tendo diversos ensaios com a sexualidade como o tema principal.

O último artigo do livro é Pirarucu Z-32: uma experiência de documentação fotográfica, cujo autor é Rafael Castanheira Pedroso Moraes. Esse trabalho é uma documentação em textos e fotos da pesca do peixe pirarucu em uma reserva no Amazonas, ação organizada pela Colônia de Pescadores Z-32. "Com a câmera fotográfica procurei registrar 
as cenas que melhor descrevessem as diferentes atividades realizadas pelos pescadores no manejo. Em 2006, o ano em que vivi seis meses entre os pescadores, produzi cerca de três mil fotografias. Nos anos seguintes esse número diminuiu, não apenas por ter ficado menos tempo na região, mas principalmente por ter documentado somente aquilo que acreditava faltar para a conclusão do trabalho. A cada ano após analisar as fotografias dos anos anteriores, percebia que determinadas atividades não haviam sido registradas ou precisavam ser melhor detalhadas imageticamente (...)" (p. 271-272). O autor conclui que buscou mais do que apenas montar um banco de imagens, mas também ajudar na preservação da memória sobre a pesca na Colônia Z-32.

Fotografia: usos, repercussões e reflexões é dedicado ao público que queira conhecer mais sobre fotografia e compreender as reflexões que a academia faz sobre o tema. A importância de uma obra tal qual a de Paulo César Boni é grande, pois artigos como os selecionados pelo autor ajudam o leitor a entender que a prática fotográfica é muito mais que mirar e apertar um botão.

BONI; Paulo César (Org). Fotografia: Usos, repercussões e reflexões. Londrina: Midiograf, 2014. 